\section{Electric Discharge Lamps}

THE War has forcibly directed attention to artificial lighting both indoors and out of doors. Black. out conditions in towns with their mentally depressing effects, their restrictions on social intercourse and their responsibility for more street accidents have emphasized man's dependence upon electric lighting. Indoors, particularly in modern factories which, like Hardwick Hall, are more glass than wall, the same black-out conditions have resulted in the continual use of artificial light even in the day-time. Specially welcome, therefore, is the interesting account of "Electric Discharge Lamps", written by V. J. Francis and H. G. Jenkins, recently published from the Research Laboratories of the General Electric Company in England. In about sixty pages an excellent technical account is given of "Osira" and "Osram" fluorescent tubes and their operating equipment. The many illustrations include spectrograms and oscillograms obtained from the tubes in operation. The story of the development of the tubes is an excellent illustration of the application of advanced academic physics in industry, and peace-time may well see the discharge lamp, historically the earlier, replacing the heated filament bulb.

\section{Malayan Wild-life}

REFERRING to the notes on Malayan wild-life in Nature of January 3, p. 17, Mr. F. F. Laidlaw writes: "the orang outan does not occur in the Peninsula, though it is of course found in Sumatra. The Malayan wild cattle is scarcely a bison, its native name should read selladăng, and the Malay name for the flying fox is kluang. The common rhinoceros, now I believe preserved, was hunted for its horn, not for ivory, and the tusks of the Malayan elephant are usually too small to be of much value. It was hunted partly as a nuisance, and partly because it was an elephant! There is a likelihood of some confusion in the use of the term Malayan, meaning 'of the Malay Peninsula', opposed to Malaysian, which refers to the Peninsula plus the great islands, Sumatra, Java, and Borneo. For this latter concept 'Sondaic' might be better. 'Sundaland' is, I believe, used to denote all the lands of the Sunda shelf".

\section{Synthetic Rubber in the United States}

IT is announced that the leading rubber, oil and chemical companies of the United States have agreed to pool their patents and technical processes to construct plants with a capacity of 400,000 tons of synthetic rubber a year. The undertaking is expected to cost about $£ 100,000,000$.

\section{Announcements}

The Bessemer Gold Medal of the Iron and Steel Institute for 1942 has been awarded to Mr. Eugene G. Grace, president of the Bethlehem Steel Company, in recognition of his valuable services to the iron and steel industries and in appreciation of all he has done to foster technical, scientific and industrial collaboration between the industries in Great Britain and the United States.

THe Committee of the Athenæum has elected the following gentlemen under the provisions of Rule II of the Club, which empowers the annual election by the Committee of a certain number of persons of distinguished eminence in science, literature or the arts, or for their public services: The Right Hon. Sir John Anderson, Lord President of the Council; Admiral of the Fleet Sir Dudley Pound, First Sea Lord of the Admiralty; General Sir Archibald Wavell, Supreme Commander, South-West Pacific Area.

Father W. McEntegart, Heythrop College, Chipping Norton, Oxford, has written referring to Prof. W. G. de Burgh's review of Dr. Osborne Greenwood's "Christianity and the Mechanists" in NATuRE of November 29, p. 637, where the following passage occurs: "Even Aquinas held that reason could not disprove the eternity of the material world and that the belief in Creation could be authorized only by revelation". Father McEntegart points out, and Prof. de Burgh concurs, that the words "in time" should have been inserted after the word "Creation".

Dr. G. F. Herbert SMItH, British Museum (Natural History), London, S.W.7, writing in connexion with the article "Nature Preservation and National Life" in NATURE of Jan. 3, p. 1, states that the Conference of the Society for the Promotion of Nature Reserves, a memorandum of which is referred to, remains in being, and correspondence for it should be addressed to him.

Sir ARThur HILL, former director of the Royal Botanic Gardens, Kew, who died on November 3, left $£ 93,379$ (net personalty $£ 92,653$ ). He bequeathed $£ 1,500$ to the chapel fund of King's College, Cambridge, to provide carved statues in wood, a small statue of Henry VI, a silver tankard dated 1686, and his Dutch tiles to King's College; $£ 200$ to the supplementary expenses fund of King's College, and to a fellow of the College his doctor of science gown and hood ; certain silver and other articles to the Archæological Museum of the University of Cambridge; $£ 1,000$ to the Bentham-Moxon Trustees of the Royal Botanic Gardens, his diaries of various journeys to the library of the Royal Botanic Gardens, and $£ 500$ to Kew Guild; his great Bible of Henry VIII to the Vaughan Library, Harrow School; $£ 1,000$ to the Royal Society; other bequests chiefly to religious bodies, and, after personal bequests, the residue as to one-eighth to King's College, Cambridge, and oneeighth to Marlborough College.

THe Medical Research Council invites applications from medically qualified women for a studentship for training in methods of experimental psychology ; preference will be given to candidates who have had some special training in physiology or neurology, or who have already had some experience in the use of research methods. The studentship will be tenable for six months during which the holder will receive training under the direction of Prof. F. C. Bartlett at Cambridge. Payment will be at the rate of $£ 350$ per annum, and the student will be expected to give her whole time to the work. The award will be made with the view of possible opportunities for research into problems arising during the War, either in the services or in industry, but no definite promise of employment after the expiry of the studentship can be given. Applications should be sent to the Secretary, Medical Research Council, c/o London School of Hygiene, Keppel Street, London, W.C.1, by February 9. 